\title{
ESTIMATION AND STIMULATION OF EXPORT POTENTIAL OF THE INNOVATIVELY ACTIVE ENTERPRISE BASED ON ECONOMIC AND MATHEMATICAL MODELLING
}

\author{
Almazbek Dooranov* \\ Department of MBA Programs, Kyrgyz National University named after Jusup Balasagyn \\ Bishkek, Kyrgyzstan, almaz.doo757@gmail.com \\ https://orcid.org/0000-0002-2198-4956 \\ Akima Orozalieva \\ Department of Economics, Management and Customs Affairs, Kyrgyz State Law University (KSLA) \\ Bishkek, Kyrgyzstan \\ https://orcid.org/0000-0001-5387-5722 \\ Aisulu Parmanasova \\ Department of Economics, Kyrgyz National University named after Jusup Balasagyn \\ Bishkek, Kyrgyzstan \\ https://orcid.org/0000-0002-5885-0812 \\ Volodymyr Katan \\ Department of Economic Cybernetics, Oles Honchar Dnipro National University, \\ Dnipro, Ukraine \\ https://orcid.org/0000-0001-9167-2619 \\ Yuliia Horiashchenko \\ Department of Marketing, University of Customs and Finance \\ Dnipro, Ukraine \\ https://orcid.org/0000-0001-7020-1412 \\ Yeugene Nagornyi \\ Research Sector, Sumy State Pedagogical University named after A. S. Makarenko \\ Sumy, Ukraine \\ https://orcid.org/0000-0003-0756-8398
}

Article history: Received 29 October 2021, Received in revised form 14 November 2021, Accepted 15 November 2021, Available online 15 November 2021

\section{Highlight}

The authors propose a new approach to stimulating the export potential of an innovatively active enterprise, based on identifying the hidden potential and expressed in the form of an economics-mathematical model.

\begin{abstract}
The study is devoted to the development of proposals for improving the assessment and stimulating the export potential of an innovatively active enterprise. The authors examined the essence and features of the activities of innovatively active enterprises, as well as the impact on their export activities. The conducted theoretical and methodological study allowed the authors to show their vision of the main components of the export potential of the enterprise, and also, in order to assess and analyze the export potential of an innovatively active enterprise, they proposed an economic and mathematical model, a feature of which is taking into account the hidden export potential, which has a significant economic impact. To stimulate the export potential of an innovatively active enterprise, the authors proposed a system of labour force motivation, as well as institutional instruments, which have a significant social impact.
\end{abstract}

\section{Keywords}

export potential; export; innovatively active enterprise; labour force; labour; mathematical modelling. 


\section{Introduction}

In the conditions of globalization, which is based, in particular, on continuous informatization and digitalization, the competition of enterprises on a national and international scale is significantly intensified, which determines the importance of providing competitive advantages for any enterprise through innovation [1]. The innovative component of the company's activities is a prerequisite for full-fledged competition in the domestic and foreign markets [2,3].

The innovative activity allows an economic entity to gain undeniable competitive advantages over other market players [4]. An enterprise typically turns to two proven activities to take a leadership position: innovation and market expansion. The synergy of these two components will allow the enterprise to successfully compete in the market, increase income, and meet the needs of the labour force.

An enterprise that generates new types of products and services can quickly become a leader in its field and be able to set standards for the development of the entire industry. This will significantly strengthen the market position of the company, add to its competitive advantages. Another equally important argument in favour of implementing innovative activities for the company will be a more rational use of its resource base for the implementation of promising innovative projects and research in its field. Among other things, the implementation of innovative activities allows the company to invest in developing various priority initiatives the required amount of funds to use in the development of the most qualified specialists. These activities will achieve the best results for the company, which will ultimately affect its approaches to new developments and the ability to determine the direction of the industry's development.

\section{Methods}

The study is based on the relationship between theory and practice; therefore, the authors cite the main theoretical and methodological aspects of the subject of research, analyzing which the authors propose ways of improvement using economic and mathematical modelling.

The methodological basis of the study is the theory of innovation activity, as well as individual elements of the concepts of development and stimulation of the export potential of the enterprise and incentives for employees. To assess and analyze the export potential of a certain business entity, an economic and mathematical model was developed that reflects the main processes of the export potential functioning and is based on two categories of the export potential of an innovatively active enterprise: actually achieved export potential and unrealized export potential (reserves).

\section{$\underline{\text { The theoretical and methodological basis }}$}

Innovatively active enterprises: essence, features, resources.

Despite the priority of innovation, today, the concept of an innovative-active enterprise is not clearly defined in domestic practice. The conducted analysis [5-7] indicates many criteria for classifying enterprises as innovation-active, used by both the official government bodies and the independent expert community. Innovation-active are enterprises that develop and implement new or improved products or services, technological processes or methods of producing products (providing services). The innovative activity of the enterprise includes the following types of work (Figure 1).

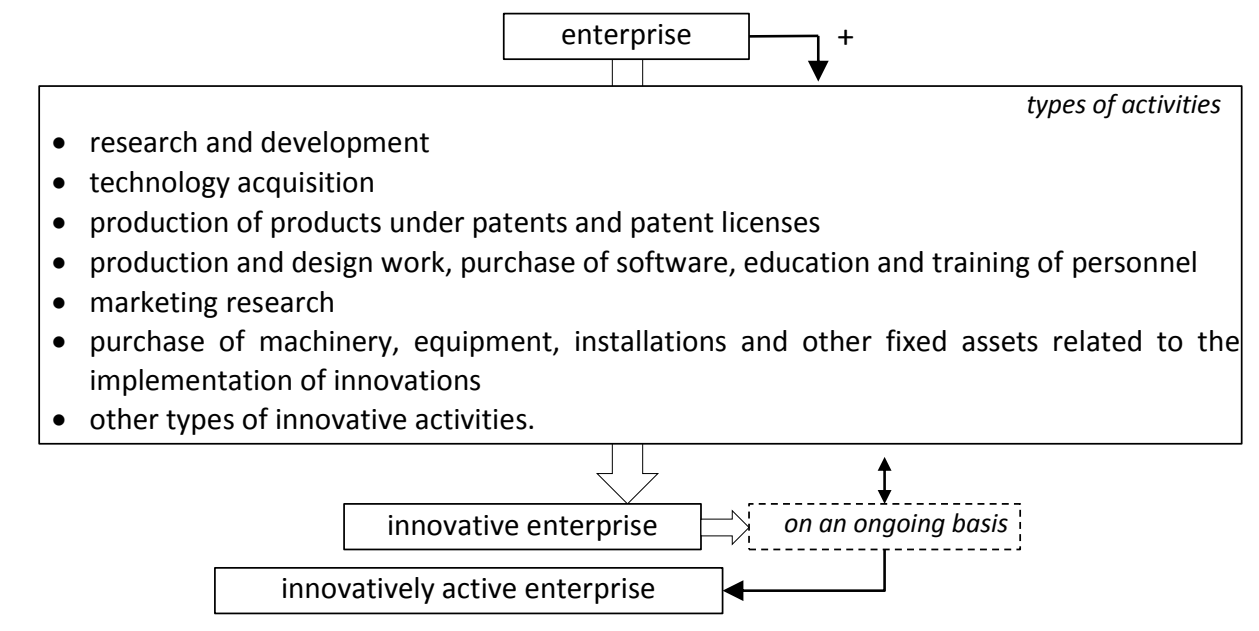

Figure 1. Distinctive features of innovatively active enterprises. Source: developed by the authors. 
Innovatively active organizations differ in the general position of management, specialists, and other workforce focused on innovative activities. This is a positive attitude to the innovative path, awareness, acceptance of its necessity and usefulness, concentrate on finding opportunities to carry out one or another activity, creating a general mood for innovation, an innovative internal atmosphere, priority attention not to obstacles, negative factors, but to positive aspects, the experience of successful innovation activity, its mechanisms, models, individual elements, borrowing such knowledge, adapting it to the conditions of specific enterprises (in contrast to the positions of passivity, surrender to difficulties, justification by objective conditions, with references to the situation of survival, paradoxical consideration of innovations not as a possible way out of a difficult situation, but as a kind of "luxury" that can only be afforded upon reaching a "good" state). Accordingly, innovatively active enterprises use various resources: available, available, necessary, effective - they make efforts to mobilize hard-to-reach resources, as many reserves as possible, in the extreme case - all possible, known ones.

First, this is the use of internal resources, the implementation of their innovative potential, which to one degree or another is available in almost all organizations, which is easiest to realize and thereby compensate for the complexity of external conditions. This includes the mobilization of the intellectual potential of the workforce, first of all, of its engineering and research departments, the involvement of all categories of personnel, including workers, in innovative activities. There is also a well-known step such as creating a specialized innovation unit, innovation groups, teams acting as initiators (stimulators) of innovation work, contributing to the introduction of innovations. It is characteristic that enterprises that do not participate in innovative development are distinguished by the failure to perform even this obvious step: establishing innovative subdivisions.

One of the essential internal factors is the presence of initiators, leaders of innovative activities, primarily among the management of the enterprise. The initiator, the main innovator, usually becomes the first person in the administration, the general director, which is quite natural because the general has the greatest competence, rights and resources, is included in connection with external organizations. Getting the "right" people, authorities and "moving the organization's development" is one of his first job functions. But the director must become a real initiator. The experience of innovative enterprises shows that the prerequisites for this are the personal qualities of the leader, intensive ties with government structures, foreign specialists and organizations, and personal experience. Initiators also play a significant role among specialists and other labor force categories due to the specific nature of the innovative activity, which presupposes precisely the innovativeness of actions [8]. Some sensible directors, realizing the timeliness of innovation but feeling burdened with turnover, delegate the initiator role either to one of the executives or to a specialized department. Various external resources are mobilized along with internal, requiring more innovative activity and becoming available as the latter is manifested. Among the first and obvious ones is interaction with research organizations for ordering and using existing innovative developments, getting help in bringing up and implementing their projects and samples. Along with the traditional institutions that have survived, many small centers, bureaus, laboratories, consulting centers, etc., have been created, which are capable of providing the possibility of at least "point" innovative development through links with industrial organizations. Infrastructure organizations such as technology parks and innovation incubators play an increasing role.

Several innovative enterprises use such external resources as interaction with foreign organizations, firms, companies, mainly manufacturing, including with the use of intermediary centers. Through such cooperation, enterprises gain access to the foreign market, acquire access (at least informational) to the latest developments, and an orientation in the innovation sphere. In the case of close cooperation or even the transformation of an enterprise into an integral part of TNCs (transnational companies), the latter reorganize the activities of the enterprise, including social conditions, while, according to foreign experts, the latter bring know-how that has not yet been introduced into the western enterprises of TNCs.

The external resources of innovative enterprises include increased attention to demand, consumers, updating marketing activities, including customers among participants and even initiators of innovations, the orientation of production not to the market in general, but to existing demand, and, if possible, the organization of export demand.

It is important to note that social factors ("human factor") are taken into account in innovative organizations. This is expressed, first of all, in working with the labor force, preparing it for creative activity, stimulating innovative activity, creating the aforementioned innovative attitude. This is an obvious and often-cited factor. But few implement this resource; Characteristically, the costs of such activities account for only $0.2 \%$ of the costs of technological innovations $[9,10]$, and the training provided is mainly technical training, traditional training. 
Export activity of innovatively active enterprises.

The problems of export activities and the elaboration of different models for the inclusion of the national economy in the world market system are sufficiently highlighted in the scientific works of foreign and domestic economists and scientists [11].

Some authors rightly argue that the export potential is an absolute value and an integrated indicator that considers the properties and characteristics of the enterprise and the market. However, if we talk about the export potential not of an enterprise but of an individual product or resource, it is necessary to make several clarifications.

The economic category "export potential" appeared in the early 90s, having come, to a certain extent, to replace the category "export base of industry", which was analyzed in the 70s and 80s XX century. When defining this category, the emphasis was shifted to the production and marketing activities of the enterprise. Subsequently, it was considered in the scientific literature as the main subject of the national economy, carrying out foreign economic activity.

There are two approaches to assessing the export potential:

- assessment of the export potential of the enterprise directly;

- assessment of the potential of foreign trade activities of the enterprise [12].

These concepts are often identified, or the concept of "export potential" is replaced by the concept of "foreign economic potential, " covering export and import operations. At the same time, the emphasis is placed on the need for the enterprise's all-around inclusion in globalization and international economic cooperation processes.

Nevertheless, when designating indicators of the potential for foreign economic activity, some indicators mainly characterize the export potential. Consequently, there is a combination of two economic categories, which, despite the relationship, require separate consideration.

The structural and logical analysis made it possible to identify the reasons determining the variety of export potential definitions [12-14]. This approach made it possible to classify them into one of two groups: essential or derived. Among the vital reasons for the variety of definitions of export potential, the following can be distinguished (Table 1).

Table 1. Reasons for the variety of definitions of export potential Source: developed by the authors based on [13,14].

\begin{tabular}{|l|l|}
\hline Causes & Description \\
\hline $\begin{array}{l}\text { Dynamism, or constant development } \\
\text { of the phenomenon }\end{array}$ & $\begin{array}{l}\text { Economic thought evolves towards the most complete, accurate and } \\
\text { modern reflection of the essence of export potential, during which } \\
\text { new approaches are formed, and existing ones are developed. }\end{array}$ \\
\hline $\begin{array}{l}\text { Polystructurality, or the variety of the } \\
\text { structure of the event the structure of } \\
\text { the phenomenon }\end{array}$ & $\begin{array}{l}\text { The export potential of an enterprise is an aggregate characteristic, } \\
\text { the outcome of the influence of many factors, and it is quite logical } \\
\text { that different researchers, depending on the goals and capabilities of } \\
\text { their scientific research, try to determine it through the most relevant } \\
\text { in practice, in their opinion, factors. }\end{array}$ \\
\hline $\begin{array}{l}\text { Polyvariety, or a variety of of } \\
\text { manifestations of the phenomenon }\end{array}$ & $\begin{array}{l}\text { The export potential characterizes enterprises of various industries, } \\
\text { regions, and countries. Accordingly, when determining the export } \\
\text { potential of objects of various levels, attempts are made to specify } \\
\text { the special, most influential factors for this particular object. }\end{array}$ \\
\hline
\end{tabular}

In the export potential of the enterprise, one can single out the key factors affecting its implementation.

Import of materials and components, equipment, technologies, know-how. The share of imported components in the cost of goods of the export assortment in the industry can be up to $40 \%$ or more since domestic production is developing more slowly than foreign production.

International cooperation. The level of competitiveness of domestic products does not always meet international requirements; therefore, enterprises need to cooperate and produce higher quality products or similar imported ones.

Entrepreneurship in free economic zones. This type of entrepreneurship will allow an enterprise to find an optimal niche for itself, in which it will be able to constantly improve the quality of products for entering the foreign market. 
Counterfeit. The presence of such products at the enterprise significantly reduces its competitiveness; therefore, it is necessary to prevent the appearance of counterfeit products on the market.

Intercultural marketing communications are currently the most promising in terms of the formation, implementation and development of export potential [15]. To achieve a synergistic effect is necessary to combine business communications of enterprises, economic missions and international exhibitions. The management of this system, both at the macro and micro levels, aims to promote enterprises to the markets of far and near abroad to monitor the effective formation and implementation of their export potential.

National government regulation. Export activity, especially for novice exporters, small and medium-sized enterprises, is a rather complex economic process, accompanied by significant risks and requiring financial costs. However, given that the stimulation of national exports is one of the promising directions that the governments of many countries adhere to, significant amounts are allocated from the state budget for these purposes: for guaranteeing and insuring export supplies and lending export-oriented industries.

The formation, implementation, assessment and stimulation of the export potential of an enterprise is a complex and multifaceted phenomenon that occurs on the market within the country under the influence of many factors of the external environment and the internal state of the enterprise.

\section{Results and discussion}

The theoretical and methodological analysis showed that entering the foreign market requires a preliminary assessment of the export potential to determine the enterprise's potential to supply and promote competitive products to the foreign market or provide competitive services in the required quantity within a certain time frame. In the context of constantly changing market conditions, modernization of society [16], complex problems of organizations [15], quarantine restrictions, the need for additional financing of enterprises [17], expansion of foreign trade relations [18] and increased competition in international markets effective use of export potential will ensure the preparation and adoption of high-quality management decisions aimed at achieving sustainable development of the innovation-active enterprise.

Based on the study, the export potential can be presented in the form of a diagram shown in Figure 2.

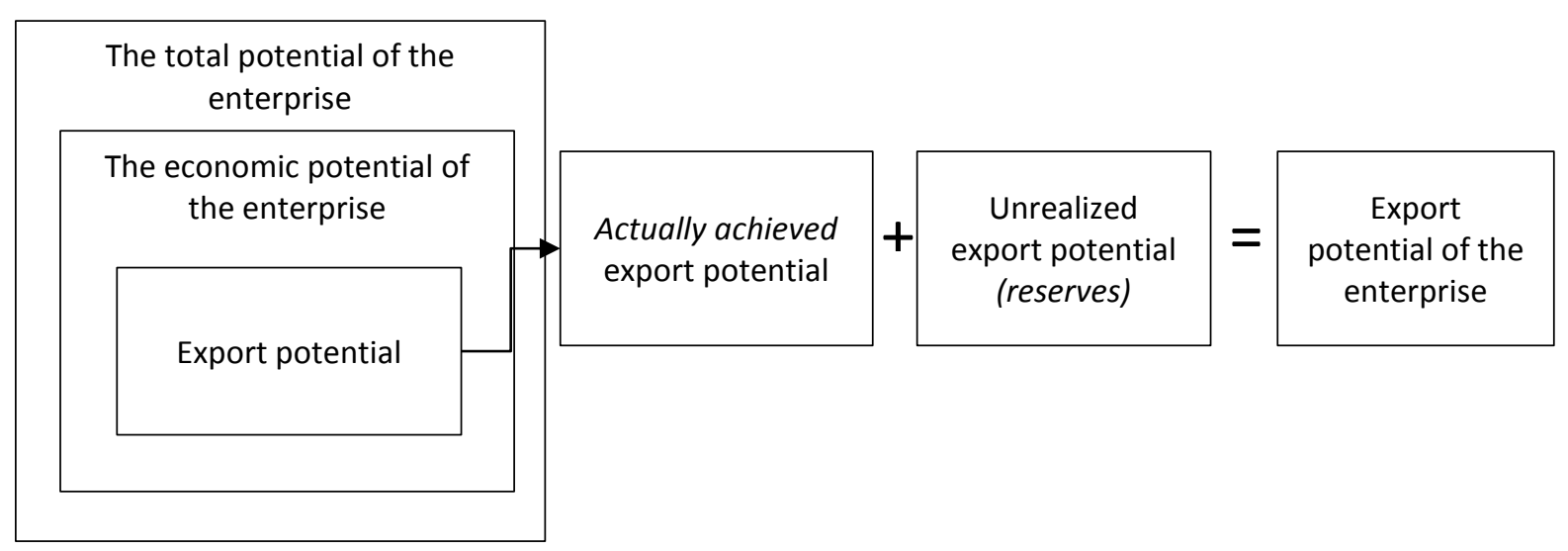

Figure 2. The main components of the export potential of the enterprise. Source: developed by the authors.

Thus, the main goal in assessing an enterprise's export potential should be identifying and implementing reserves for increasing the efficiency and profitability of an enterprise's export activities, increasing production of products competitive in foreign markets with minimal costs of production and financial resources.

Unrealized export potential (reserves, latent potential) - assets that do not provide a specific advantage at this stage, although they can be transformed into basic funds in the future.

Thus, it is necessary to work out an instrument, using economic and mathematical modelling, which makes it possible to define different indicators for assessing this potential in the conditions of the corresponding (best) system of economic activity of the innovation-active enterprise, aimed at identifying hidden reserves [19].

Given the specificity of the research subject, the integral method of calculating the export potential of an enterprise is more often used, which we improve by introducing two categories of exports and which allows us to more accurately reflect the capabilities of an innovative enterprise in the foreign market, using indicators that are weighted in a certain way among themselves. The advantage of this method is simplicity in calculations and unambiguously interpretable results: 


$$
K_{p}=\sqrt{\alpha * P_{a a} *(1-\alpha) * P_{r e s}}
$$

where $\alpha$ is the coefficient of the contingency of export potential;

$P_{a a}$ is the aggregate estimate of the actually achieved export potential of the enterprise and is calculated using the formula:

$$
P_{a a}=K_{P P} * K_{P R O F_{a}} * K_{T M_{S h}} * K_{P R O F_{p r o d}}
$$

where $K_{P P}$ is an indicator of the ratio of the production program to the production capacity of the enterprise;

$K_{P R O F_{a}}$ is an indicator of the profitability of production assets;

$K_{T M_{S h}}$ is the share of products in the target market;

$K_{P R O F_{\text {prod }}}$ is an indicator of product profitability;

$P_{\text {res }}$ - is the aggregate estimate of the unrealized export potential (reserves) of the enterprise and is calculated using the formula:

$$
P_{\text {res }}=K_{R} * K_{P M_{s h}} * K_{C_{m}} * K_{P R O F_{s a l}}
$$

where $K_{R}$ is an indicator of the ratio of production and sales;

$K_{P M_{S h}}$ is the share of products in the potential market;

${ }^{K} C_{m}$ is the share of marketing costs in the total amount of costs;

$K_{P R O F_{s a l}}$ is an indicator of the profitability of sales;

Foreign trade activity is subject to economic conditions, which is expressed in unstable oscillatory processes of the enterprise. During the upturn, the economic situation improves, the possibilities of production and sale of export products expand, which contributes to a greater manifestation of the hidden export potential of the enterprise. During the deterioration of the economic situation (recession, crisis), the export potential of the enterprise, on the contrary, decreases, but it can also be adjusted due to the intensification of production, the economic use of resources, recircular production, and the creation of the necessary basis for raising production.

Choosing three stages of the market environment for the characteristics of oscillatory processes: growth, stabilization and decline, we will establish certain values of the contingency coefficient (Table 2).

Table 2. Coefficients of the conjugation of actually achieved and unrealized export potential. Source: developed by the authors.

\begin{tabular}{|l|l|l|}
\hline \multirow{2}{*}{ Market conditions } & Contingency coefficient \\
\cline { 2 - 3 } & actually achieved potential & unrealized export potential \\
\hline Recession & 0.7 & 0.3 \\
\hline Stabilization & 0.5 & 0.5 \\
\hline Rise & 0.3 & 0.7 \\
\hline
\end{tabular}

In sum, the coefficients of the conjugation of the achieved and unrealized export potential should be equal to one.

In sum, the coefficients of the contingency of domestic and latent export potential should be one. 
The level of development of the export potential of the enterprise reflects a specific number, which allows one of the following conclusions to be drawn:

1. The product has significant shortcomings, and one should refrain from entering the foreign market.

2. The product has several disadvantages, but they can be overcome by connecting the hidden potential and eventually entering the external market.

3. Nothing hinders export activity; the goods can be brought to the external market shortly.

The analysis of the export potential based on the developed mathematical model made it possible to determine approaches to its assessment in the context of the rational organization of the economic activity of the relevant innovation-active enterprise.

To assess the effectiveness of the use of export potential, we propose to take effect the following volume of exports, which achieves the maximum level of profit:

$$
F\{x\}=Y\left(p r_{i j} * x_{i j}\right) \rightarrow \max
$$

$$
x_{i j} \leq a_{i}, x_{i j} \leq b_{j}, x_{i j} \geq 0
$$

where $n$ is the number of importers;

$i=1,2 \ldots, m$-number of products;

$x_{i j}$ - the optimal amount of the $\mathrm{i}$-th product to be exported to the j-th country;

$p r_{i j}$ - profit from exports to the j-th country per unit of the i-th product;

$F\{x\}$ - objective function;

$a_{i}$ - the volume of products for export;

$b_{j}$ - market capacity of the j-th country for the i-th type of exported products.

Concerning stimulating export potential, which is largely reserved, the study found that one of the main problems of low export potential is the lack of communication with target markets. The solution to this problem is the workforce; the staff, both top management and ordinary employees establish contacts and search for foreign partners depend. In this case, the best measures are material incentives for employees based on their performance.

For a well-thought-out and approved system of bonuses and incentives for personnel to really work, motivating people to work more productively, it is necessary to improve the system of material incentives (Figure 3).

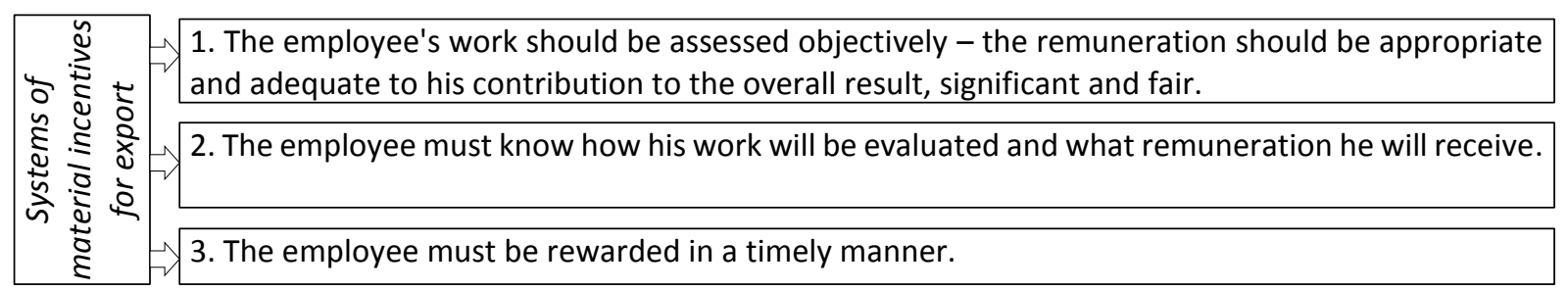

Figure 3. Improving the system of material incentives. Source: developed by the authors.

If the team has an oppressive atmosphere, ill will, tension, staff turnover, review your system of material incentives. An experienced HR manager (or even a psychologist) can be attracted to the team and entrust him with this job.

For enterprises, export promotion can include any measures aimed at ensuring stable development and realization of the export potential of the industry represented by individual economic entities, in particular:

- unimpeded return of VAT to exporters;

- ensuring the development of technical and sanitary standards for environmental friendliness of production processes and product standards by international requirements at the expense of the state budget or international grants; 
- the attraction of investments for the modernization of the technical and technological base of the industry;

- full application of the quota system;

- maintaining a competitive real exchange rate, which forms adequate price incentives;

- creation of a mechanism for financial support for exports, first of all, lending, guaranteeing and insurance of export supplies and loans for improving the infrastructure and social base (qualified workforce), providing information and consulting services, promoting the exhibition and fair activities of national firms abroad, subsidizing research works.

All organizational and economic measures to assess and stimulate the level of efficiency of the export potential of the innovation-active enterprise should be implemented systematically.

\section{Impact}

The research touches upon two areas of influence: economic and social.

Economic Impact: the authors propose a conceptual basis for assessing and stimulating the export potential of an enterprise, which, unlike the existing ones, is based on the identification and development of hidden export potential. An interesting contribution to the development of practical economic methods is developing an economic and mathematical model that allows one to determine various indicators for assessing the latent potential in the conditions of rational (optimal) organization of economic activity of the relevant business entity at identifying hidden reserves.

Social Impact: according to the results of the study, which revealed that the low export potential of the enterprise, among other things, is influenced by the lack of connection with the target markets. To solve this problem, the authors propose material incentives for employees based on the results of their work, improving the system of material incentives for employees, which, unlike the existing ones, is based on the principles of objectivity, transparency and timeliness.

\section{Conclusions}

All organizational and economic measures to assess and stimulate the improvement of the efficiency of the use of export potential in the context of international integration processes should be implemented systematically, in a relationship that will change the negative trends of its development. It is important to note that there is still a lack of comprehensive research with specific recommendations on economic policy measures and methodologies for their use to qualitatively expand and intensify export activities and improve the position of national exports in the world market. That is why the expediency of further research is also caused by the problem associated with the urgent need to develop and implement a comprehensive strategy for the formation and use of the export potential of the country, which necessitates the development of theoretical and methodological foundations of active state economic policy and qualitative factors of the economic development of the country.

\section{Conflict of interest}

There are no conflicts to declare.

\section{Acknowledgments}

This research has not been supported by any external funding.

\section{References}

[1] L. Halkiv, O. Karyy, I. Kulyniak, S. Ohinok, Modeling and forecasting of innovative, scientific and technical activity indicators under unstable economic situation in the country: Case of Ukraine, in: Commun. Comput. Inf. Sci., 2020: pp. 79-97. https://doi.org/10.1007/978-3-030-61656-4_5.

[2] O. Bilovodska, A. Kholostenko, Z. Mandrychenko, O. Volokitenko, Innovation management of enterprises: Legal provision and analytical tools for evaluating business strategies, J. Optim. Ind. Eng. 14 (2021) 89-96. https://doi.org/10.22094/JOIE.2020.677820.

[3] O. Garachkovska, O. Sytnyk, D. Fayvishenko, I. Taranskiy, O. Afanasieva, O. Prosianyk, Strategic management of brand positioning in the market, Adv. Sci. Technol. Eng. Syst. 6 (2020) 947-953. https://doi.org/10.25046/aj0601104.

[4] I. Vakhovych, B. Satyvaldieva, A. Dooranov, M. Slynko, O. Marchenko, I. Salivonchyk, Smart specialization of the region as a tool for modernizing innovative development, Estud. Econ. Apl. 39 (2021). https://doi.org/10.25115/eea.v39i5.4800. 
[5] Bashynska I.O., Models of integrated marketing communications forming for innovatively active machine engineering enterprises, Econ. Ann. (2012) 52-54.

[6] R.K. Serkebayeva, A.A. Korzhengulova, Z.M. Shaukerova, B.Z. Uteyev, A.M. Ziyatdinov, Practice and assessment of financing of innovative projects in Kazakhstan, Espacios. 38 (2017) 14.

[7] L. Halkiv, O. Karyy, I. Kulyniak, S. Ohinok, Innovative, scientific and technical activities in Ukraine: Modern trends and forecasts, in: Proc. 2020 IEEE 3rd Int. Conf. Data Stream Min. Process. DSMP 2020, IEEE, 2020: pp. 321-324. https://doi.org/10.1109/DSMP47368.2020.9204148.

[8] T. Mamytbek uulu, M. Aibashev, Labor migration and development of human resources of the Kyrgyz Republic, Population (Paris). 24 (2021) 154-164. https://doi.org/10.19181/population.2021.24.2.14.

[9] O. Golichenko, S. Samovoleva, Mapping risk factors of innovation activity enterprises, Int. J. Innov. Reg. Dev. 5 (2013) 149. https://doi.org/10.1504/ijird.2013.055238.

[10] M. Kopytko, Y. Ilkiv, MECHANISM OF ENTERPRISE SECURITY ACTIVITY MANAGEMENT OF INNOVATIONACTIVE ENTERPRISE: SUMMARY AND STRUCTURE, Soc. Leg. Stud. 8 (2020) 119-129. https://doi.org/10.32518/2617-4162-2020-2-119-129.

[11] Y. Rahimi, I. Matyshenko, R. Kapitan, Y. Pronchakov, ORGANIZATION THE INFORMATION SUPPORT OF FULL LOGISTIC SUPPLY CHAINS WITHIN THE INDUSTRY 4.0, Int. J. Qual. Res. 14 (2020) 1279-1290. https://doi.org/10.24874/IJQR14.04-19.

[12] I.A. Markina, Management of the 21St Century: Globalization Challenges, (2019) 260. https://www.pdaa.edu.ua/sites/default/files/academicdepartment/kafedramenedzhmentu/monographpoltava2018-ilovepdf-compressed-1-260.pdf.

[13] A.I. Volkova, I.A. Karachev, Export potential growth factors for a small innovative enterprise, Financ. Theory Pract. 20 (2016) 31-38.

[14] M. Karimbergenova, A. Nurgaliyeva, G. Kerimbek, S. Bespalyy, L. Moldashbayeva, THE DEVELOPMENT OF REGIONAL EXPORT POTENTIAL, REPORTS. 3 (2019) 160-167. https://doi.org/10.32014/2019.25181483.87.

[15] I. Bashynska, Improving the Tariff Policy of Urban Passenger Transport Based on International Experience, TEM J. 9 (2020) 1588-1596. https://doi.org/10.18421/TEM94-34.

[16] A. Smutko, Z. Asanov, T. Ergeshova, MODERNIZATION AND KYRGYZ TRADITIONAL SOCIETY, EurasianUnionScientists. 5 (2021) 38-41. https://doi.org/10.31618/esu.2413-9335.2021.5.84.1302.

[17] O. Poberezhets, O. Kovalova, M. Iorgachova, TRANSFORMATION PROCESSES OF THE IPO MARKET: UKRAINIAN AND WORLD EXPERIENCE, Balt. J. Econ. Stud. 4 (2018) 178-183. https://doi.org/10.30525/2256-0742/2018-4-2-178-183.

[18] O. Prokopenko, Y. Kichuk, O. Ptashchenko, I. Yurko, M. Cherkashyna, Logistics Concepts to Optimise Business Processes, Estud. Econ. Apl. 39 (2021). https://doi.org/10.25115/eea.v39i3.4712.

[19] A.I. Borodin, A.A. Tatuev, N.N. Shash, E. V. Lyapuntsova, V.V. Rokotyanskaya, Economic-mathematical model of building a company's potential, Asian Soc. Sci. 11 (2015) 198-204. https://doi.org/10.5539/ass.v11n14p198. 